\title{
Systematic literature review of Brazilian research on multivariate control charts
}

Renan Mitsuo Ueda ${ }^{1}$, Federal University of Santa Maria, Camobi, Santa Maria, Rio Grande do Sul, Brazil Leandro Cantorski da Rosa ${ }^{2}$, Federal University of Santa Maria, Camobi, Santa Maria, Rio Grande do Sul, Brazil Wesley Vieira da Silva ${ }^{3}$, Federal University of Santa Maria, Camobi, Santa Maria, Rio Grande do Sul, Brazil Ícaro Romolo Sousa Agostino 4 , Federal University of Santa Catarina, Trindade, Florianópolis, Santa Catarina, Brazil Adriano Mendonça Souza ${ }^{5}$, Federal University of Santa Maria, Camobi, Santa Maria, Rio Grande do Sul, Brazil

\section{RESUMO}

Objetivo - Este artigo tem como objetivo apresentar uma Revisão Sistemática da Literatura (RSL) sobre estudos no Brasil com aplicações de cartas de controle multivariadas indexadas em periódicos da Web of Science.

Desenho / metodologia / abordagem - Os passos seguidos foram: síntese de forma detalhada sobre as características gerais do corpus, análise de co-citações e redes de colaboração; e verificação da coocorrência de termos no corpus do texto. A revisão sistemática da literatura foi realizada com os protocolos de Biolchini et al. (2007), Kitchenham (2004) e Tranfield, Denyer e Smart (2003). Os artigos foram selecionados na base de dados Web of Science, e após a aplicação dos filtros, restaram 29 artigos para a composição do corpus.

Resultados - Percebeu-se uma tendência de crescimento das publicações e a existência de internacionalização das pesquisas sobre o tema. O periódico mais utilizado como meio de divulgação foi o Microchemical Journal. Essa análise evidenciou autores relevantes para pesquisas nesta área: Harold Hotelling, Douglas Montgomery e John Frederick MacGregor. Foram apontados importantes pesquisadores brasileiros que atuam principalmente na indústria farmacêutica e de biodiesel.

Originalidade / valor - Não foram encontrados artigos que realizassem uma revisão sistemática da literatura de pesquisas brasileiras sobre gráficos de controle multivariados. As principais contribuições deste manuscrito relacionamse ao aumento do conhecimento científico na área de análise multivariada e bibliométrica.

Palavras-chave - Gráficos de controle multivariados. Revisão sistemática da literatura. Análise bibliométrica.

\section{ABSTRACT}

Purpose - This paper aims to present a Systematic Literature Review (SLR) of studies in Brazil with applications of multivariate control charts indexed in journals on the Web of Science.

Design/methodology/approach - The following steps were carried out: a detailed synthesis was performed on the general characteristics of the corpus, co-citation and collaboration networks analyzed; and a co-occurrence of terms in the text corpus was verified. A Systematic Literature Review was carried out using the protocols set out by Biolchini et al. (2007), Kitchenham (2004) and Tranfield, Denyer and Smart (2003). Papers were selected from the Web of Science database, and after applying filters, results for 29 articles were given to compose the corpus.

Findings - A tendency was found for an increase in publications, along with more international research on the issue. The journal most used for publication was the Microchemical Journal. This analysis provided relevant authors for research in this area: Harold Hotelling, Douglas Montgomery, and John Frederick MacGregor. Important Brazilian researchers were highlighted who work mainly in the pharmaceutical and biodiesel industry.

Originality/value - No articles were found that had carried out a Systematic Literature Review of Brazilian research on multivariate control charts. The main contributions to this manuscript related to an increase in scientific know-how in the area of multivariate and bibliometric analysis.

Keywords - Multivariate Control Charts. Systematic literature review. Bibliometric analysis.

1. Prédio 13, Centro de Ciências Naturais e Exatas - Av. Roraima, 1000 - Sala 1205C - Camobi, Santa Maria - RS, 97105-900, renan.mitsuo@hotmail.com, https://orcid.org/0000-0002-3529-1499; 2. leski78@ hotmail.com, https://orcid.org/0000-00034696-6866; 3. wesvsilva@gmail.com, https://orcid.org/0000-0001-5354-8676; 4. icaroagostino@gmail.com, https://orcid.org/0000-0002-4813-0109; 5. amsouza.sm@gmail.com; https://orcid.org/0000-0002-1562-2246.

UEDA, R.M.; ROSA, L.C.; SILVA, W.V.; AGOSTINO, J.R.S.; SOUZA, A.M. Systematic literature review of Brazilian research on multivariate control charts. GEPROS. Gestão da Produção, Operações e Sistemas, v.16, nº 1, p. 122 - $149,2021$. DOI: http://dx.doi.org/10.15675/gepros.v16i1.2677 


\section{INTRODUCTION}

Control charts are the main support tools for performing Statistical Process Control (SPC). The control charts seek to detect deviations of representative parameters that may negatively impact the operation of the process and, besides, investigate the atypical sequencing of the series analyzed. Therefore, the reasons for using process control charts are: improved productivity through reduction of rework, prevention of defects, effective worker participation, availability of information about the process, as well as its productive capacity (MONTGOMERY, 2016; MARCONDES FILHO, FOGLIATTO; OLIVEIRA, 2011; FAISAL et al., 2018).

Maboudou-Tchao, Silva and Diawara (2018) believe that the processes of industrial manufacturing modernization contemplate several situations that require the simultaneous monitoring of the quality characteristics involved, and the separate control of these characteristics can lead to interpretations mistakes about such quality.

In the literature, several types of multivariate control charts are found, such as, Hotelling's T² (GALAVERNA et al., 2018; DARMANTO; ASTUTIK, 2017; HENNING et al., 2014), multivariate control chart of exponentially weighted moving averages (EWMA) (HAQ; GULZAR; KHOO, 2018; ABREU; SCHAFFER, 2017; KIM; JEONG; ELSAYED, 2017; UGAZ; SÁNCHEZ; ALONSO, 2017), Multivariate Accumulated Summaries Graph (MCUSUM) (NIDSUNKID; BORKOWSKI; BUDSABA, 2018; SUKPARUNGSEE et al., 2017).

Subsequently, the elaboration of the corpus of research was based on the systematization of the research protocol developed in the works of Biolchini et al. (2007), Kitchenham (2004) and Tranfield, Denyer and Smart (2003) who followed the methodological rigidity imposed on this type of analysis. The research was structured in three stages: i) detailed realization of the synthesis with the general characteristics of the corpus, ii) verification of collaboration and co-citation networks; and iii) study of the textual corpus in relation to the co-occurrence of terms.

From the point of view of the relevance of the research to the Brazilian literature, this research is considered relevant, due to the analysis of the Brazilian publications in multivariate control charts following the methodological rigor of a Systematic Literature Review (SLR). Considering the theoretical contribution, the research seeks to investigate the 
corpus of the research through mapping the publications on the subject, besides seeking to evidence the main multivariate control charts used in Brazil, as well as its main areas of application.

\section{THEORETICAL FOUNDATION}

\subsection{Systematic Literature Review}

The Systematic Literature Review (SLR) is a synthesis of studies published in journals that clearly presents the objectives, materials and methods used. In addition, an SLR must be conducted by a clear and reproducible methodological procedure (GREENHALGH, 1997).

SLR uses an explicit and rigorous methodology in order to perform text identification, critical opinion and synthesis of the most relevant studies on the theme addressed. The elaboration of a consistent protocol is extremely important in an SLR as it will be part of the previous planning and will guide all research (BARROSO et al., 2003).

Such approach differs from narrative bibliographic reviews because in SLR there is a systematization of research, where there is a sequencing of steps, that is, the method is explicit, the techniques have standardization and the study can be easily reproduced by other researchers. For the direction of an SLR, the inclusion and exclusion criteria of the studies found must be previously elaborated (MCDONALD et al., 2006).

The meta-analysis is the statistical treatment in relation to the results obtained from the systematic review. Several authors performed SLR in various areas of knowledge and many of them used meta-analysis, Pedrini et al. (2018), Soriano, Álvarez and Valdés (2018) concentrated their studies on social and public relations. Ruiz-Negrón et al. (2019), Andor and Fels (2018), Mondolo (2019) in the economic area, Graeff et al. (2019), Archer et al. (2019), Gutierrez-Salazar and Medrano-Vizcaino (2019), in the area of ecology and biology, Schmitz, Figueira and Lampron (2019), Newton et al. (2019), Chan et al. (2019) in the area of education, Deliberador, de Mello and Batalha (2019) and Assis et al. (2017) in transport engineering.

In this study, the elaboration of the research corpus was based on the systematization of the protocol developed in the works of Biolchini et al. (2007), Kitchenham (2004) and Tranfield, Denyer and Smart (2003) that followed the rigidity. methodology imposed on this type of analysis. The research was structured in three steps: i) detailed synthesis with the 
general characteristics of the corpus; ii) verification of collaboration and co-operation networks; and iii) study of the textual corpus in relation to the co-occurrence of terms.

Therefore, SLR corresponds to a fundamentally evidence-based activity, aiming to summarize much information in one document, thus facilitating accessibility to information and categorizing studies in terms of reliability and relevance. This research aims to carry out an SLR on the theme "multivariate control charts" in studies conducted in Brazil.

\subsection{Multivariate Control Charts}

Statistical Process Control (SPC) is a set of tools and techniques related to quality monitoring and control, corresponding to one of the efficiency control strategies most used in industrial manufacturing processes. This set of tools corresponds to a management philosophy, where the focus is to provide stability and continuous improvement of products, services and processes, through production engineering and statistics techniques (MABOUDOU-TCHAO; SILVA; DIAWARA 2018; MASON; YOUNG 2002).

This methodology is linked to effective quality control, as it enables the worker to be able to monitor his process in real time, thus generating a greater commitment on the part of the employee regarding the quality of service performed (YIN et al., 2015).

Xiang (2013) and Morales (2013) believe that the SPC represents a prevention methodology, because through quality tools we seek to perform the production process detailing, evaluating its discontinuity based on specific standards.

According to Faisal et al. (2018) control charts are the main support tools for performing statistical process control. The control charts seek to detect the deviations of representative parameters that can negatively impact the process operation and further investigate the atypical sequencing of the analyzed series.

Qiu (2018) believes that control charts are a quality management tool because, besides contemplating technical aspects, they also provide an organizational environment for continuous improvement. According to Marcondes Filho, Fogliatto and Oliveira (2011) and Wang et al. (2018), control charts are quantitative management tools used to support statistical control of product quality in the production process, reducing out-of-specification product volume and costs. related to production.

According to Lyu and Chen (2009) in industrial sector, there are several situations in which two or more variables must be simultaneously monitored, where independent control 
can lead to wrong decisions. Multivariate control charts are able to point out the correlation and dependence between the investigated variables by analyzing the influence of the variables together (PAN; LEE 2010).

In several situations autocorrelation between the analyzed variables is present, where one of the main causes is the gradual wear and tear of machines and equipment over time (MASON; YOUNG 2002). Thus, the use of multivariate control charts allows the process monitoring to be performed in real time by the employees themselves, ensuring the reduction of the variability of the production system, contributing to the continuous improvement of the company.

\section{METHODOLOGICAL PROCEDURES}

A protocol was systematized according to the methodological rigidity imposed to this type of analysis, implying in the corpus of the research. The SLR will be performed using as basis the protocols proposed in the works developed by Biolchini et al. (2007), Kitchenham (2004) and Tranfield, Denyer and Smart (2003). The papers were selected from the Web of Science database using the term "Multivariate control charts". The use of the research protocol had the objective of extracting papers that were in line with the proposed theme. The choice of the Web of Science journal base is multidisciplinary and encompasses more than 12 thousand of the world's leading journals as it provides a broader view of research output in a variety of fields including social sciences, arts and humanities (DRESCH; LACERDA; JÚNIOR, 2015). Several authors have already used the Web of Science Journal base to carry out a systematic literature review (REIS et al., 2019; MONTERO; AGUADED; FERRES, 2017; HUANG et al., 2015; MICHELS; FU, 2014).

Based on the results of the research, some search filters were performed and some criteria for inclusion and exclusion of the sample were elaborated. The period of collection of the primary data of this research refers to November of 2018 where 529 documents related to the subject were found altogether. The filter established for "Countries and Regions" was used in order to extract papers associated with Brazilian educational institutions. 32 papers were described altogether describing studies on multivariate control charts in the country. It should be highlighted that a period of time was not defined for the selection of papers in the searches made in the Web of Science database. Allowing all the work on multivariate control charts 
present in this base had the same chance of being found (TEIXEIRA; SOUZA 2017, PRADO; CAMPO 2018).

In order to select only papers published in journals, a second filter was applied, that is, papers were excluded from the research, as well as abstracts, with 30 publications remaining. After reading the abstracts of each of the remaining 30 papers, it was verified that only one papers not aligned with the researched topic, so it was opted for its exclusion, and the corpus of the research was 29 papers.

According to Zupic and Carter (2015), some research questions will guide the analysis, such as who are the specialists in the fields of research on multivariate control letters? How have these surveys developed over time? And what are the main topics associated with the study of multivariate process control charts? The steps for conducting the research are presented in Figure 1. It contains the criteria used for the inclusion or exclusion of the papers found on the subject.

Figure 1 - Systematic Literature Review steps and resulting number of publications

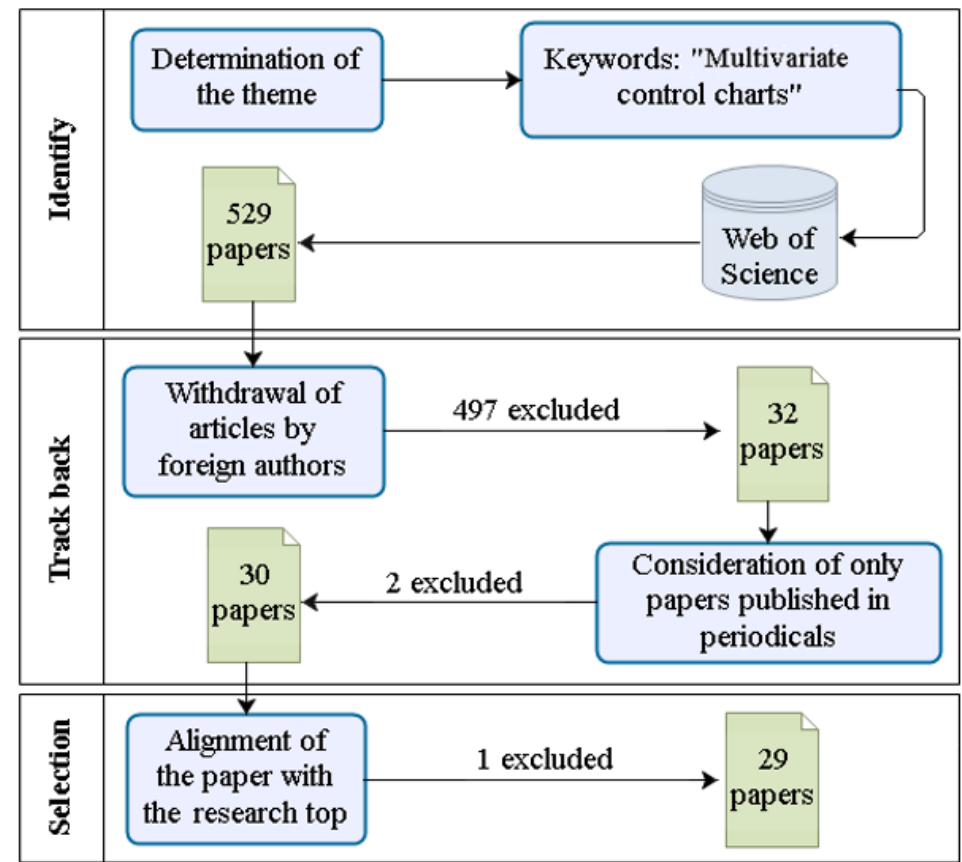

Source: Created by the authors, 2019. 
The phases for the dissemination of knowledge, were: detailed presentation of corpus of the research in multivariate control charts; analysis of co-citation and collaboration networks; and analysis of co-occurrence of terms in the textual corpus.

It is worth noting that the textual corpus was defined based on the steps recommended by Almeida and Goulart (2017), where the authors emphasize the importance of minimizing selection bias. In this sense, the selection stages of the primary studies included the application of previously denoted filters, related to the languages, to the reputation of the journal, aiming to assure the quality of the studies and the content analysis performed by three independent reviewers, thereby solving the disagreements with a fourth reviewer.

The next phase related to the analysis of collaboration and co-citation networks was aimed at identifying the most relevant authors of the textual corpus and verifying the interrelationship between the teaching institutions linked to each of the authors of the works analyzed. Subsequently, in the analysis phase of co-occurrence of relevant terms in the textual corpus, it was identified the research focus in terms of objectives, methodology and results.

For these analyzes described above, bibliometric packages were used: Gephi 0.9.2 (BASTIAN; HEYMANN; JACOMY, 2009) and Iramuteq 0.7 (RATINAUD; DÉJEAN, 2009; VIZEU CAMARGO; JUSTO, 2013). It should be noted that the results of this bibliometric study are supported by the three laws of bibliometrics: a) Lotka's Law (1926), which estimates the degree of relevance of authors in a given area of knowledge; b) Bradford's Law (1953), which verifies the degree of relevance of the periodicals; and c) Zipf's Law (1949), which measures the frequency of occurrence and co-occurrence of words in the text.

\section{RESULTS AND DISCUSSION}

The present section was developed following the three stages of knowledge dissemination proposed by Trafield, Denyer and Smart (2003) for the development of an SLR: Detailed presentation of the corpus of the research in multivariate control charts in surveys conducted in Brazil; Analysis of co-activity and collaboration networks; and Analysis of co-occurrence of terms in the textual corpus. 


\subsection{Detailed Presentation of the Research Corpus}

Initially, it was tried to elaborate the science map from the work proposed by (RAFOLS; PORTER; LEYDESDORFF 2010), that used bibliometric data of the world literature, aiming to show how the different researchers are interconnected, besides analyzing, based on the papers of the textual corpus, how such maps may or may not cover the main topics of a given topic, as well as help the development agencies identify the research frontiers and predict their investments better.

The results presented in Figure 2 emphasize the number of authors and co-authors who have an institutional bond in one or more Brazilian higher education institutions, who published the theme "multivariate control charts".

Figure 2 - Number of authors and co-authors with institutional bond

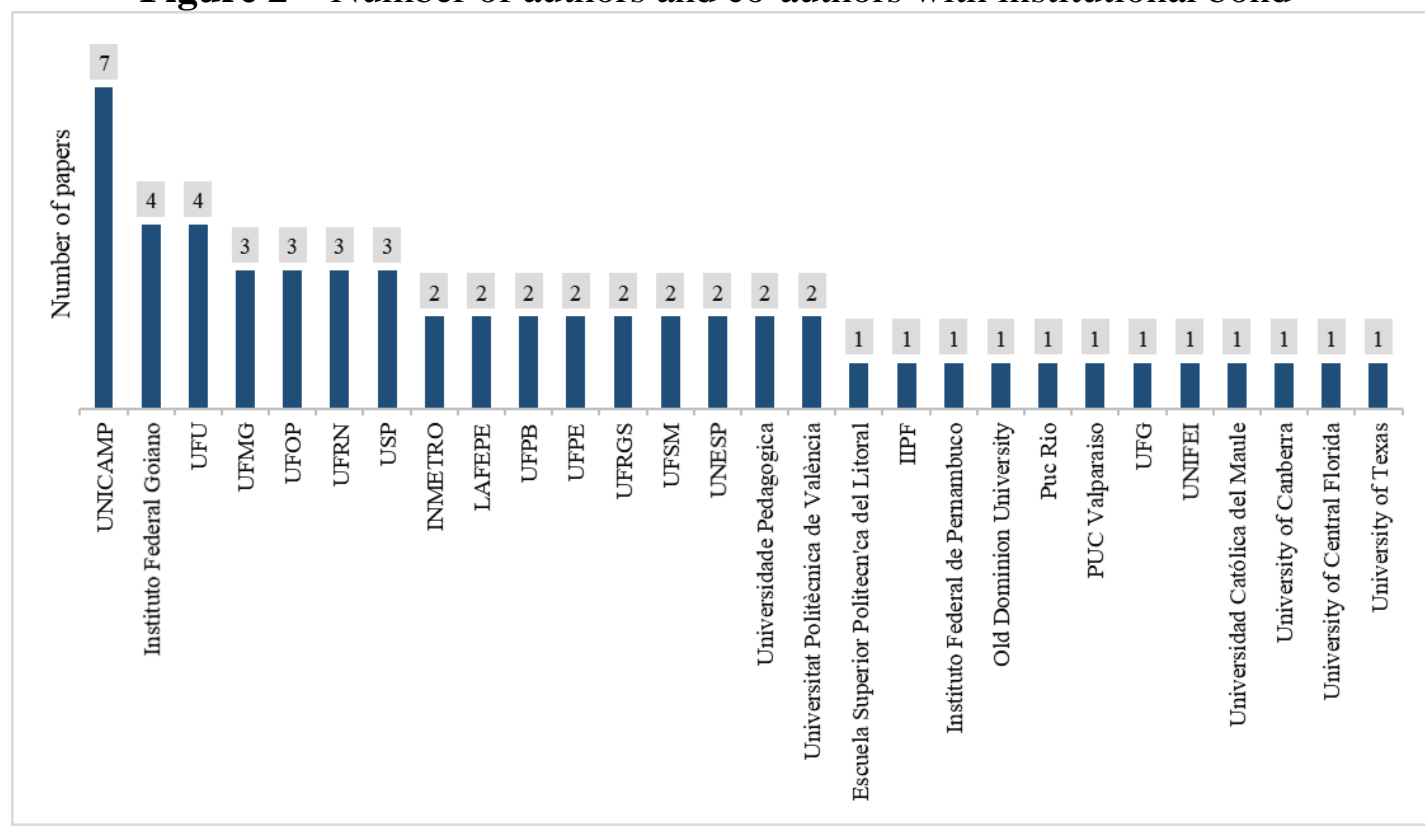

Source: Created by the authors, 2019.

Figure 2 shows that the authors and co-authors who have an institutional bond in one or more educational institutions that published the graphic multivariate control of processes were: State University of Campinas (UNICAMP) with 7 authors; Goiano Federal Institute (IFGoiano) and Federal University of Uberlândia (UFU) with 4 authors/co-authors each; followed by Federal University of Minas Gerais (UFMG), Federal University of Ouro Preto (UFOP), Federal University of Rio Grande do Norte (UFRN) and University of São Paulo 
(USP) with 3 authors. The other institutions not mentioned had less than 2 authors who have an institutional bond and are mentioned in the works.

It should be noted that in making the previous survey, it is also possible to note the cooperation between different institutions, while at the same time, some authors have bonds with more than one institution and different states of the federation, which causes a certain author or even co-author may represent more than one state. Figure 3 shows the distribution of the number of educational institutions by states of the federation in the research corpus.

Figure 3 - Number of Institutions by Brazilian States of the Federation

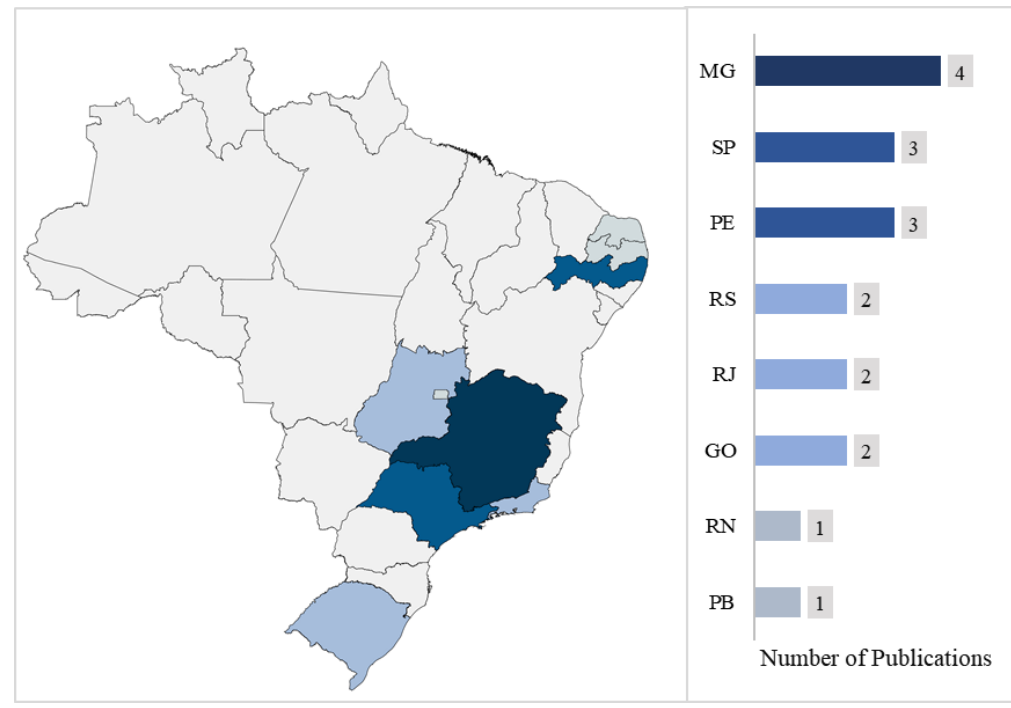

Source: Created by the authors, 2019.

It can be seen from Figure 3 that the State with the highest representation was Minas Gerais with a total of four educational institutions, followed by São Paulo and Pernambuco, which had a total of three institutions each. As previously mentioned, in this work, a period of time was not defined for the selection of papers in the Web of Science journals. Thus, Figure 4 shows the number of papers published over time, which includes the year 2004 and 2018. 
Figure 4 - Publication number over time

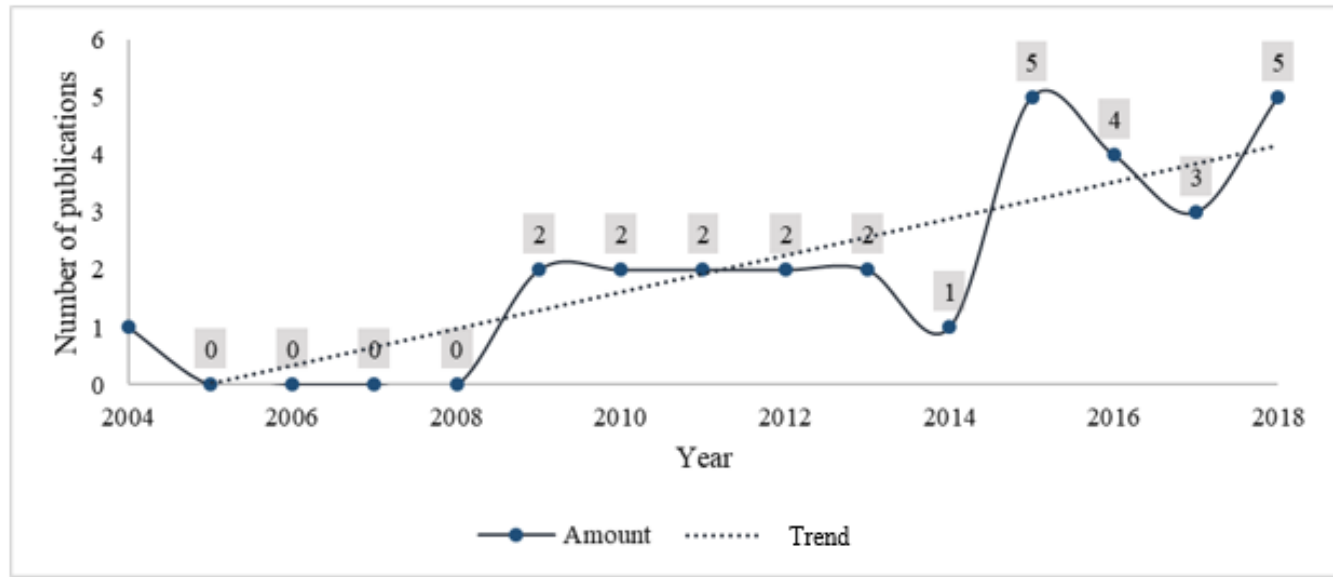

Source: Created by the authors, 2019.

As shown in Figure 4, there is a growing trend in publications over the years, indicating the potential for growth of research on this topic in Brazil, especially from 2015 with seventeen published works. The studies were also analyzed in terms of relevance when considering the number of citations received by the evaluated papers, and the results are presented in Figure 5.

Figure 5 - Most cited papers of the textual corpus

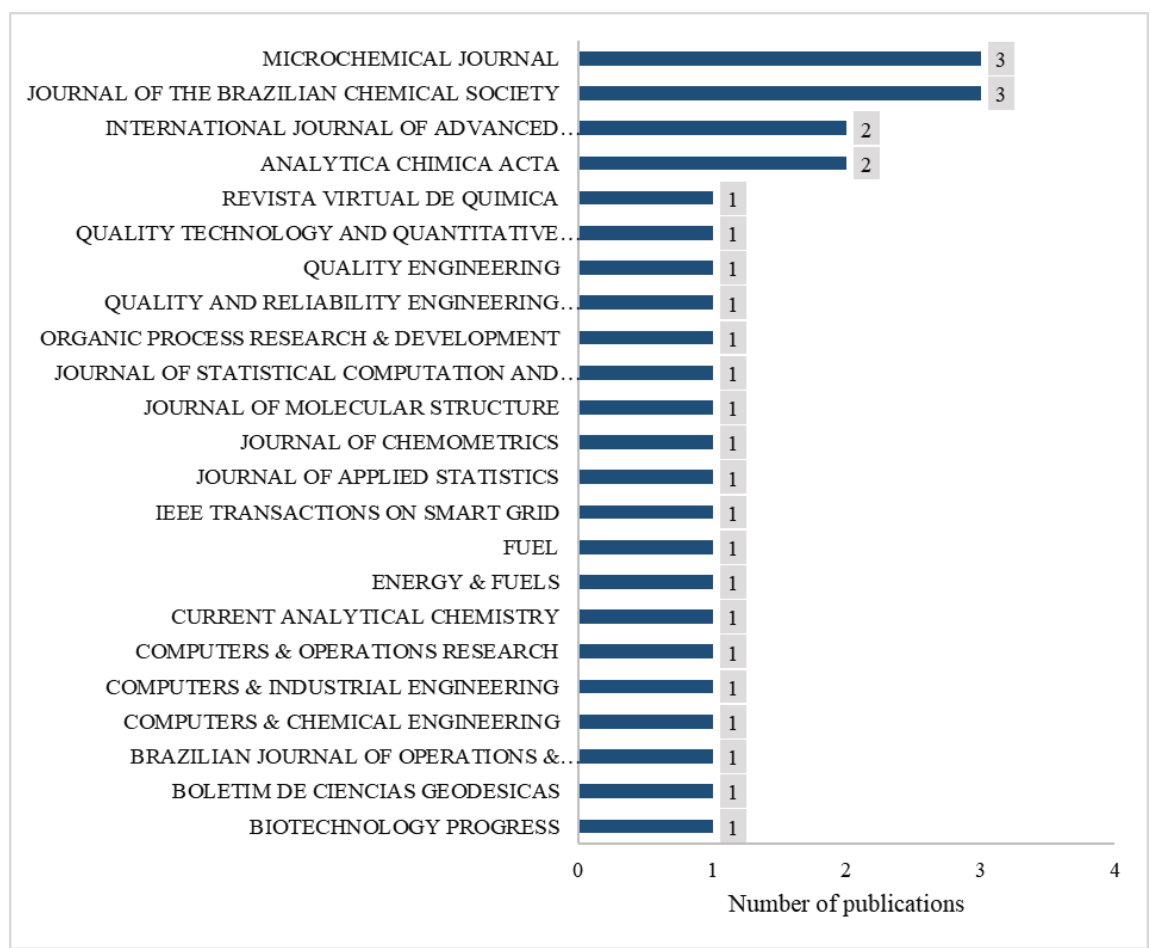

Source: Created by the authors, 2019. 
It should be noted that Figure 5 contains papers with five or more citations, corresponding to a total of 136 citations received from the papers evaluated. Thus, the most cited papers were published by Borin and Poppi (2004) with twenty three citations corresponding to $16.91 \%$ of the total citations received; Oliveira, Rocha and Poppi (2009) with twenty one citations corresponding to $15.44 \%$ of the citations received, Rocha and Poppi (2010) with nineteen citations, corresponding to $13.97 \%$ of citations received, Avila et al. (2012) with sixteen citations that refers to $11.76 \%$ of the citations, Rocha et al. (2010) with ten citations, corresponding to $7.35 \%$ of the citations received, Machado, Costa and Marins (2009) and Costa et al. (2015) with eight citations each, corresponding to $5.88 \%$ of the citations, Sitoe et al. (2017) with six citations corresponding to $4.41 \%$ of the total citations, and finally, Balestrassi et al. (2011), Rocha and Poppi (2011), Moraes et al. (2014), Tôrres, Grangeiro Junior and Fragoso (2015), and Sitoe et al. (2016) with five citations each, which corresponds to $3.67 \%$ of the total citations.

The journal's reputation was analyzed through CAPES WebQualis, offering the scientific community the ex-post parameters that allow the description of the dynamics and density of contributions around a theme or specificity. It was evaluated the periodicals of the textual corpus according to the Bradford's Law, according to Alabi (1979), that the decreasing order of productivity of papers of a certain subject in the respective scientific journals will allow the establishment of groups divided in an exponential way. Thus, through the productivity of journals, it is possible to establish the nucleus and areas of dispersion about a given subject in the same set of journals. Table 1 shows the number of journals and their published papers, considering the thematic multivariate graph controls and based on the bibliometric law of Bradford. 
Table 1 - Number of Papers and Corpus Papers Published

\begin{tabular}{|c|c|c|c|c|}
\hline $\mathbf{N}$ & Journals Evaluated & Papers & Cumulative frequency & Zones \\
\hline 1 & Journal of The Brazilian Chemical Society & 3 & 3 & Zone 1 \\
\hline 2 & Microchemical Journal & 3 & 6 & Zone 1 \\
\hline 3 & Analytica Chimica Acta & 2 & 8 & Zone 1 \\
\hline 4 & $\begin{array}{l}\text { International Journal of Advanced Manufacturing } \\
\text { Technology }\end{array}$ & 2 & 10 & Zone 1 \\
\hline 5 & Biotechnology Progress & 1 & 11 & Zone 2 \\
\hline 6 & Boletim de Ciências Geodésicas & 1 & 12 & Zone 2 \\
\hline 7 & $\begin{array}{l}\text { Brazilian Journal of Operations \& Production } \\
\text { Management }\end{array}$ & 1 & 13 & Zone 2 \\
\hline 8 & Computers \& Chemical Engineering & 1 & 14 & Zone 2 \\
\hline 9 & Computers \& Industrial Engineering & 1 & 15 & Zone 2 \\
\hline 10 & Computers \& Operations Research & 1 & 16 & Zone 2 \\
\hline 11 & Current Analytical Chemistry & 1 & 17 & Zone 2 \\
\hline 12 & Energy Fuels & 1 & 18 & Zone 2 \\
\hline 13 & Fuel & 1 & 19 & Zone 2 \\
\hline 14 & IEEE Transactions on Smart Grid & 1 & 20 & Zone 2 \\
\hline 15 & Journal of Applied Statistics & 1 & 21 & Zone 3 \\
\hline 16 & Journal of Chemometrics & 1 & 22 & Zone 3 \\
\hline 17 & Journal of Molecular Structure & 1 & 23 & Zone 3 \\
\hline 18 & Journal of Statistical Computation and Simulation & 1 & 24 & Zone 3 \\
\hline 19 & Organic Process Research \& Development & 1 & 25 & Zone 3 \\
\hline 20 & Quality and Reliability Engineering International & 1 & 26 & Zone 3 \\
\hline 21 & Quality Engineering & 1 & 27 & Zone 3 \\
\hline 22 & Quality Technology and Quantitative Management & 1 & 28 & Zone 3 \\
\hline 23 & Revista Virtual de Química & 1 & 29 & Zone 3 \\
\hline
\end{tabular}

Source: Created by the authors, 2019.

Table 1 shows that four of the twenty-three journals, namely: Journal of the Brazilian Chemical Society, Microchemical Journal, Analytica Chimica Acta and International Journal of Advanced Manufacturing Technology, which represents a total of 17.39\%. Located in the first zone (Z1), characterized as the strong point of the list of evaluated journals, that is, a small number of highly productive journals. This zone has a total amount of ten published papers, which represents $34.48 \%$ of the total published papers of the textual corpus.

In the second zone (Z2), which makes up a total of nine journals of the twenty-three evaluated representing $39.13 \%$ of this total, namely: Biotechnology Progress, Bulletin of Geodetic Sciences, Brazilian Journal of Operations \& Production Management, Computers \& Chemical IEEE Transactions on Smart Grid have a total of nine published papers, representing $31.02 \%$ of the total published papers of the corpus textual.

In the third zone (Z3), which represents a total of ten of the twenty-three journals evaluated, it represents about $43.48 \%$ of the total periodicals, namely: Journal of Applied 
Statistics, Journal of Chemometrics, Journal of Molecular Structure, Journal of Molecular Structure, Journal of Statistical Computation and Simulation, Organic Process Research and Development, Quality and Reliability Engineering International, Quality Engineering, Quality Technology and Quantitative Management and Virtual Journal of Chemistry, has a total of ten published papers, which represents $34.48 \%$ of the total of published papers of the textual corpus.

The grouping technique was used with the factorial analysis technique. When viewing the science from the bibliometric map, the analysis of nineteen factors was considered, and it enabled the identification of several fields of science and elements of world scientific production. In this case, the factorial analysis used aims to evaluate the description and variability between the correlated variables observed, seeking to reduce them to a smaller number of such variables. Further details on the technique of factor analysis can be found in Hair et al. (2009).

The maps shown in Figure 6(a) and Figure 6(b), respectively, evidence the degree of interdisciplinary of a set of publications. Notice in this same figure that the heat diagram indicates the areas of research with greater concentration.

Figure 6(a) - Science map of the areas of the corpus searched

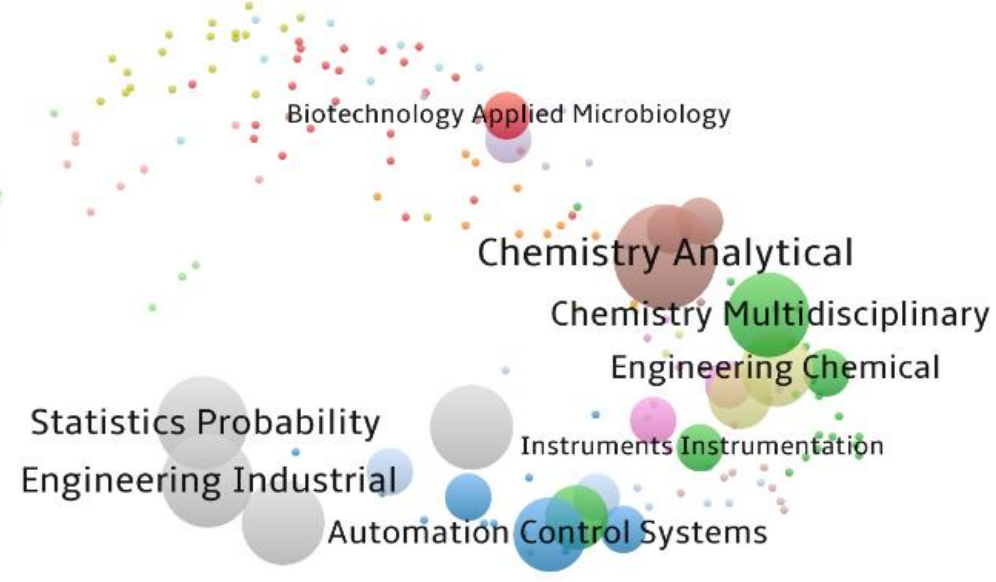

Source: Created by the authors, 2019 . 
Figure 6(b) - Density map of the areas of the corpus searched

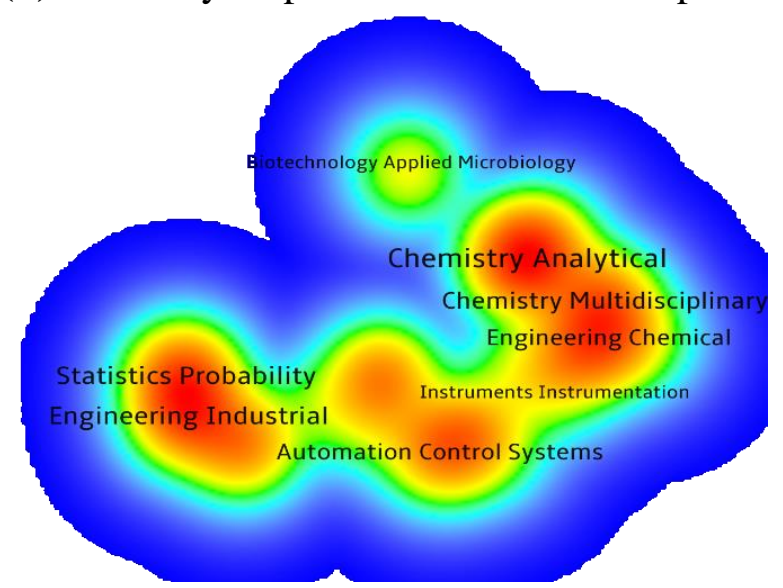

Source: Created by the authors, 2019.

Note that in both of the graphs shown in the previous figures, they show the factors with the highest intensity: Analytical Chemistry and Industrial Engineering. This occurrence can be explained by the large number of publications in these areas of knowledge. It is noteworthy that there are other fields of science that also present significance in this research, such as: Statistics Probability, Automation Control Systems and Multidisciplinary Chemistry.

\subsection{Analysis of Collaboration and Co-citation Networks}

The analyzes of collaboration and co-citation of institutions and authors were carried out with the objective of verifying which institutions and authors are most frequently cited by a more recent institution or author, in the Brazilian context, following the research protocol proposed by Tranfield, Denyer and Smart (2003), Kitchenham (2004) and Biolchini et al. (2007) and based on the collaborative network formulation, as it can be seen in Figure 7. 
Figure 7 -Network of Collaboration between Teaching Institutions

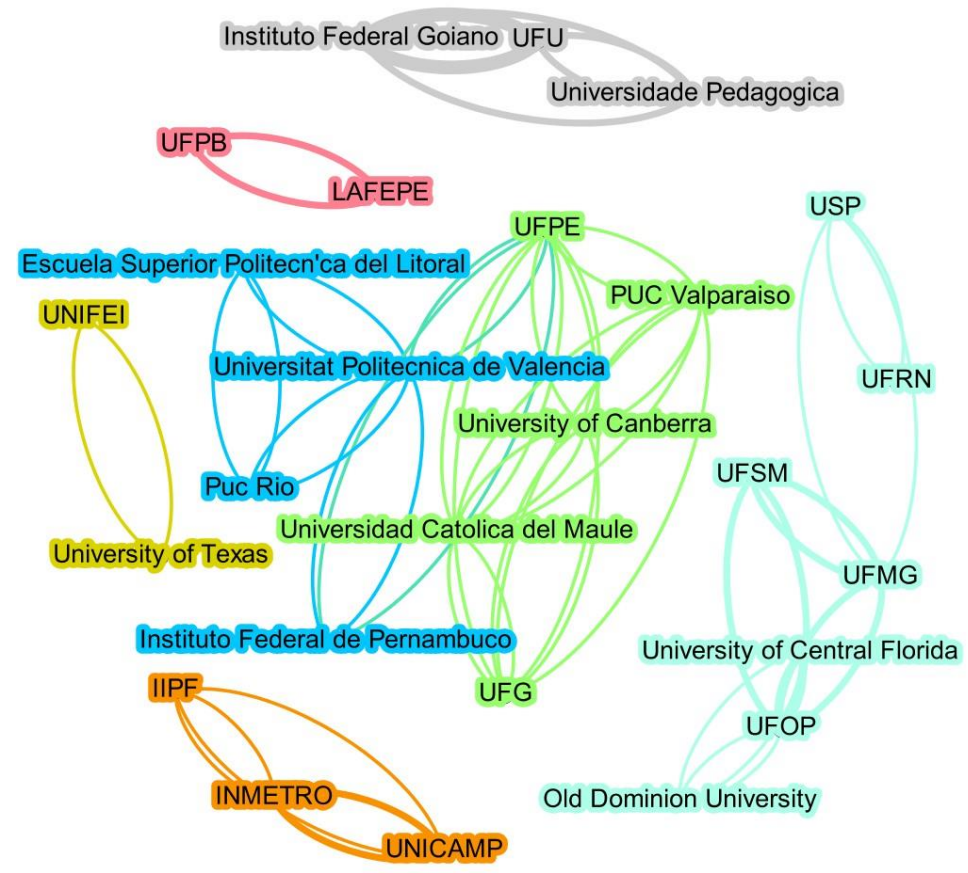

Source: Created by the authors, 2019.

It is possible to note through Figure 7 the formation of seven clusters (separated by color), where Cluster 1 is made up of the University of São Paulo (USP), Federal University of Rio Grande do Norte (UFRN), Federal University of Santa Maria (UFSM), Federal University of Minas Gerais (UFMG), Federal University of Ouro Preto (UFOP) and the foreign institutions University of Central Florida (UCF) and Old Dominion University (ODU), indicating the possibility of internationalization and at the same time development of similar studies on this subject in the area of knowledge.

Cluster 2 is formed by the Federal University of Pernambuco (UFPE), Pontifical Catholic University of Valparaiso (PUC Valparaíso), Federal University of Goiás (UFG) and foreign Institutions University of Canberra (UC), Universidad Católica del Maule, being possible to note the partnership between national and foreign educational institutions. The Cluster 3 is composed of the Pontifical Catholic University of Rio de Janeiro (PUC-Rio), Federal Institute of Pernambuco (IFPE), and the foreign institutions Universitat Politecnica de Valencia (UPV) and Escuela Superior Politecnica del Litoral (ESPOL) also suggesting the internationalization of research in multivariate control charts. Besides, the second and third largest clusters are interrelated, indicating further internationalization of the research carried out on this subject, as well as the partnership between the educational institutions of Brazil. 
Cluster 4 analyzed is formed by the State University of Campinas (UNICAMP), the National Institute of Metrology, Quality and Technology (INMETRO) and the International Institute for Pharmaceutical Research (IIPF), evidencing the partnership of higher education institutions with federal and institutes of specific areas. The Cluster 5 is formed by Goiano Federal Institute (IFG), Federal University of Uberlândia (UFU) and by the foreign teaching institution Pedagogical University (UP), again evidencing the internationalization as a strong point of research on the subject explored.

Cluster 6 is formed by Federal University of Itajubá (UNIFEI) and University of Texas (UT), indicating once again the collaboration between national and foreign institutions. At last, there is the formation of Cluster 7 that is formed between Federal University of Paraíba (UFPB) and Pharmaceutical Laboratory of Pernambuco (LAFEPE), which indicates the existence of partnerships between higher education institutions with related companies to the State Department of Health.

It is possible to see though the formation of the clusters that there is no evidence of a geographical dependence in terms of collaboration, that is, the spatial distance between the educational institutions does not prevent the formation of partnerships between them. Another important finding relates to the internationalization of the research on the subject, since the corpus textual was collaborated with eight foreign institutions of education, located in Chile, the United States, Mozambique, Ecuador, Spain and Australia.

In evaluating the co-citation of cited references of the textual corpus, it is sought to investigate the frequency with which two authors are simultaneously quoted by a third author, consequently if the fact of a larger number of researchers citing the same two publications will have as a consequence a greater probability that the double citation is not a mere coincidence, it refers to a related subject between the publications cited in the research area.

Figure 8 shows the co-occurrence of the most cited authors in the references of the 29 papers analyzed, and the length of the vertices is equivalent to the Eigenvector Centrality (PRELL, 2011) statistic. The co-citation network was distributed through the algorithm of Fruchterman and Reingold (1991), being carried out the grouping and considered the "Modularity Class" statistic for its analysis (NEWMAN, 2006). 
Figure 8 - Network of co-citation of the cited references

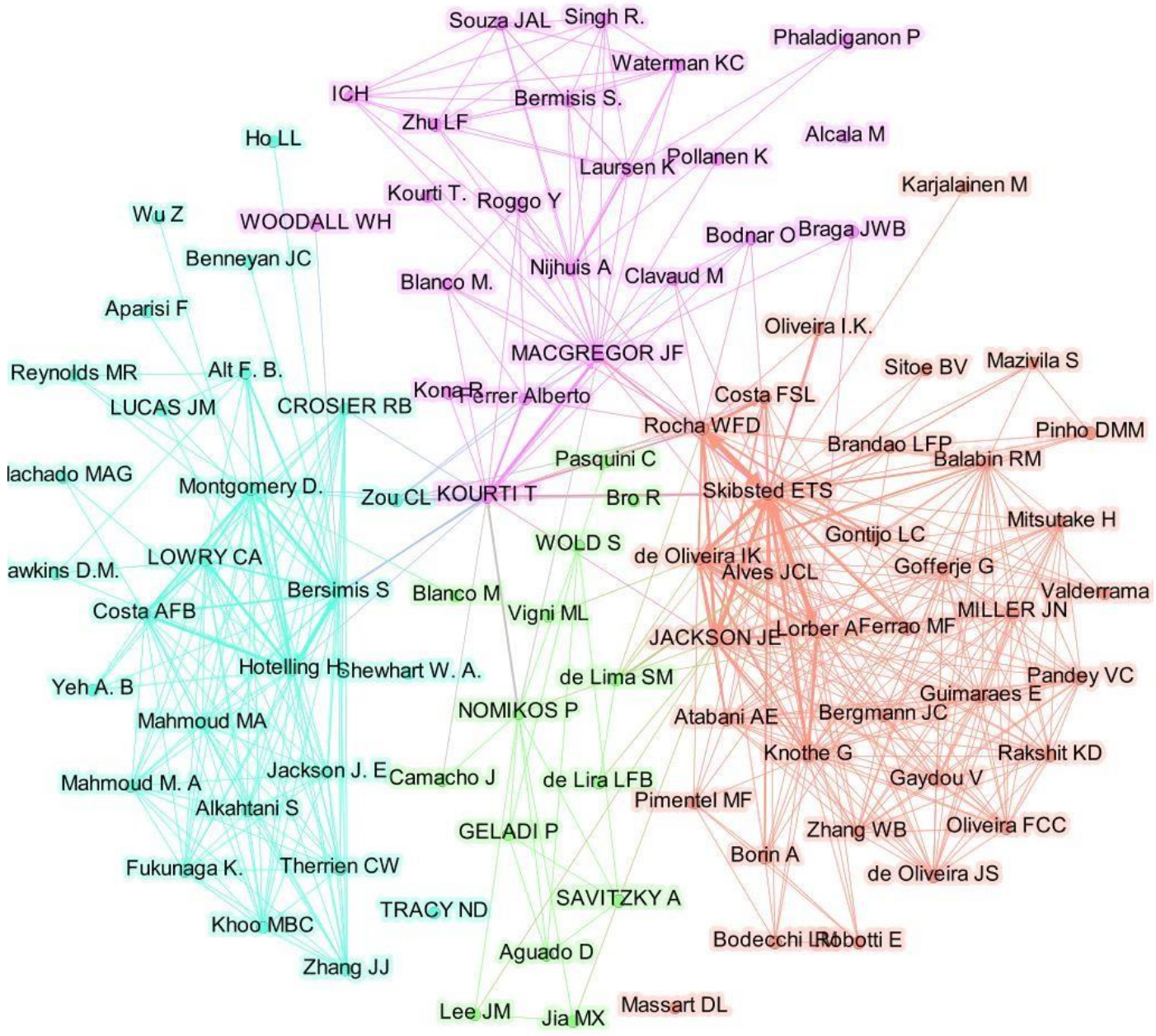

Source: Created by the authors, 2019.

Figure 8 shows the formation of four large groups (separated by color). Note that the authors with the highest amount of co-citation are grouped in the cluster highlighted in red, followed by the authors of the blue cluster with a high co-citation occurrence number like the purple cluster and, finally, the fourth cluster highlighted in green color which is formed by the authors with the lowest incidence of co-citation.

It is still possible to highlight the importance of relevant authors on the subject, such as Harold Hotelling, Douglas Montgomery, and John Frederick MacGregor. Harold Hotelling became popular for the presentation of the Hotelling $\mathrm{T}^{2}$ distribution, along with their respective hypothesis tests and confidence intervals. Another outstanding author is Douglas Montgomery, researcher on the themes of Experiment Design, Quality Engineering, and Industrial Statistics. John Frederick MacGregor is a statistician who works in the field of 
statistical process control, being his pioneering work in the area of multivariate analysis focused on manufacturing processes.

Other outstanding researchers from the academic point of view were also evidenced in the network of cited references being among them: Theodora Kourti, Erik Skibsted, Edward Jackson, Abdulaziz Atabani, Sotiris Bersimis, Alberto Ferrer and Avraham Lorber once great part of these authors concentrate their studies in the area of health or biodiesel.

In the co-citation network are found important Brazilian researchers on the subject, such as Werickson Rocha, Jefferson de Oliveira, Fernanda Saadna Lopes da Costa, Júlio Alves, Maria Fernanda Pimentel. Werickson Rocha is a technologist -researcher in the Chemometrics and Qualimetry of INMETRO and he is also a professor in several teaching programs. Fernanda Saadna Lopes da Costa is a researcher in the area of biospectroscopy, multivariate classification and infectious-contagious tropical diseases. Researchers and chemists Jefferson de Oliveira, Júlio Alves and Maria Fernanda Pimentel work especially in the field of chemometrics, being much of their studies focused on the biofuels sector.

The centrality statistics of the fifteen most co-cited authors in their references, on the subject of multivariate control charts are presented in Table 2.

Table 2 - Top 15 authors of the co-citation network's Statistics of centrality

\begin{tabular}{c|c|c|c}
\hline $\mathbf{N}$ & Authors & Degree & Eigenvector Centrality \\
\hline 1 & Kourti, T. & 126 & 0.733333 \\
\hline 2 & Rocha, W.F.D. & 122 & 0.717391 \\
\hline 3 & Skibsted, E.T.S. & 110 & 0.682759 \\
\hline 4 & Jackson, J.E. & 102 & 0.673469 \\
\hline 5 & De Oliveira, I.K. & 100 & 0.668919 \\
\hline 6 & Costa, F.S.L. & 104 & 0.660000 \\
\hline 7 & Atabani, A.E. & 90 & 0.647059 \\
\hline 8 & Bersimis, S. & 90 & 0.647059 \\
\hline 9 & Alves, J.C.L. & 88 & 0.642857 \\
\hline 10 & Pimentel, M.F. & 86 & 0.638710 \\
\hline 11 & Ferrer, A. & 82 & 0.630573 \\
\hline 12 & Macgregor, J.F. & 78 & 0.618750 \\
\hline 13 & Lorber, A. & 88 & 0.618750 \\
\hline 14 & Montgomery, D. & 76 & 0.618750 \\
\hline 15 & Hotelling, H. & 74 & 0.614907 \\
\hline
\end{tabular}

Source: Created by the authors, 2019.

The data presented in Table 2 corroborate the centrality of the authors, in which the degree corresponds to the number of relations that each author has in the co-citation network, and the eigenvector centrality statistic determines the degree of centrality. The highest degrees 
of co-occurrence are obtained by Theodora Kourti, Werickson Rocha and Erik Skibsted - with 126,122 and 110, respectively.

\subsection{Analysis of Co-occurrence of Terms in the Textual Corpus}

The cloud of words refers to the organization or even to the grouping of words according to their frequency of occurrence, based on the lexical content, as well as on the representational centrality of the research corpus. This section has as premise to point out the focus of the objective of the studies analyzed, the approach of the methodologies used, besides the main results. This way, Figure 9 shows the presentation of the words that were extracted from the summaries of the textual corpus, considering their frequencies of occurrences.

Figure 9-Cloud of Words Extracted from the Abstracts of the Textual Corpus

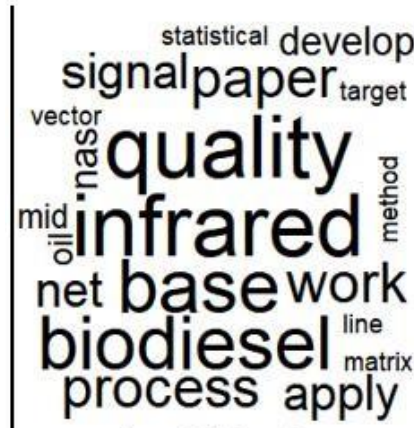

A - Objective

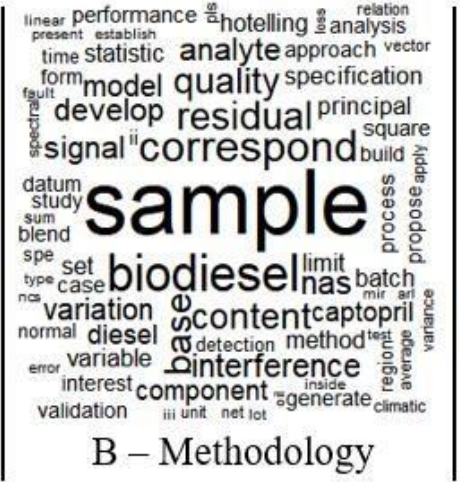

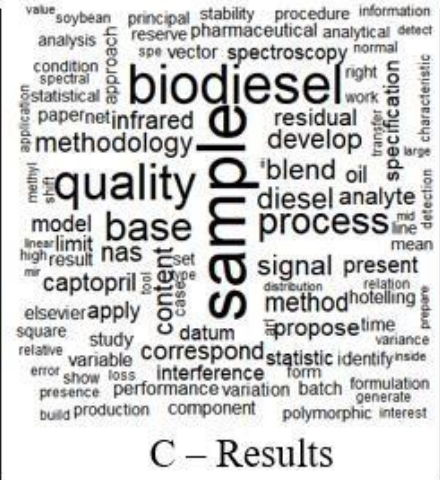

Source: Created by the authors, 2019.

Note that the words arranged in Figure 9 were grouped into three large sets: objectives, methodologies, and research results. In this case, the words "chart", "control", "monitor" and "multivariate" were excluded because they were directly related to the subject. In addition, we considered the words with the incidence number greater than or equal to 5 in the 29 evaluated papers. See in the same figure that the objective of the several studies analyzed was to use the multivariate control charts for the quality monitoring, having a greater application focus in the pharmaceutical and biodiesel industries. The focus on the pharmaceutical industry is explained by the high incidence of the word "infrared", which refers to the use of infrared spectrometers in research.

Regarding the methodologies used in the studies, the incidence of the words "sample", "residual", "variation", "model", "develop" and "base", suggest that the surveys present a 
quantitative approach. The studies are focused on the selection of samples, in order to investigate the residues and their variation, besides the elaboration and/or application of multivariate control charts. In the results of the primary studies, the incidence of the words "sample", "quality", "biodiesel", "process" and "base" occurs, indicating the application of multivariate control charts in a composite database from the selection of a sample. In addition, the studies indicated satisfactory results for the quality of processes using multivariate control charts, especially for the biodiesel industry.

Subsequently, through a textual corpus of the abstracts of the 29 papers selected, the analysis of similarity of co-occurrence was carried out, which is anchored in the graph theory, making it possible to identify the co-occurrences between the words and their result, indicates the connection between them, assisting in the identification of representation. In this case, the words with the incidence number greater than or equal to ten were considered, obtaining the following result (Figure 10).

Figure 10 - Similarity analysis of the co-occurrence of terms in the textual corpus

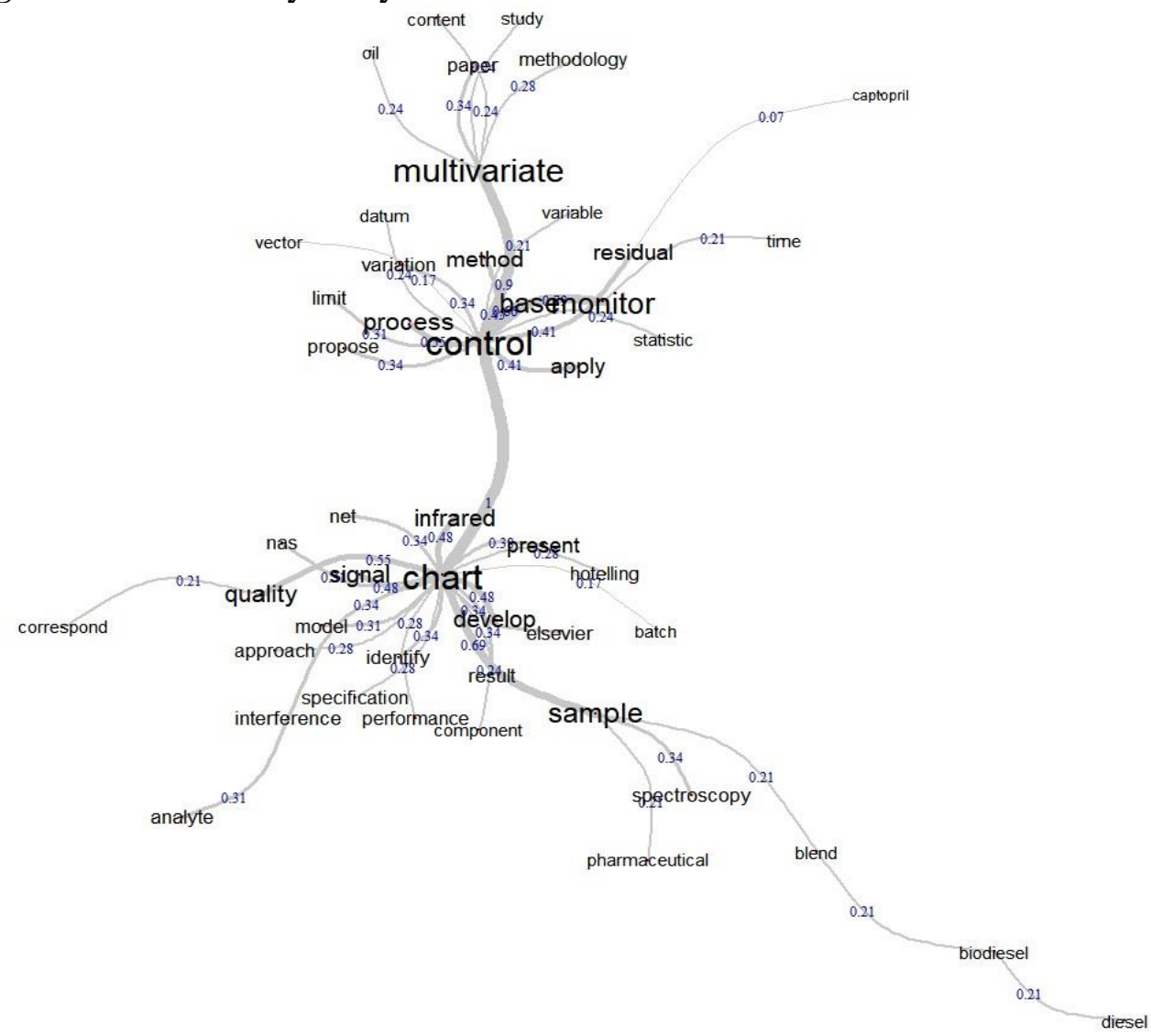

Source: Created by the authors, 2019. 
Through the analysis of co-occurrence of words it is possible to perform an inspection on the subject and to point out the patterns of the existing research in the literature. Figure 10 shows that there is evidence of the link between the words "multivariate", "control" and "chart", indicating that the studies analyzed are related to the development and/or application of this type of chart.

There is co-occurrence between the word "multivariate" with the terms "study", "methodology" and "paper", indicating that the studies used two or more variables. Another co-occurrence happens between the word "control" and the terms "apply", "process", "residual" and "variation", pointing out that the studies aim at the application of multivariate graphs for the control of processes, residues and variation. And at last, the co-occurrence of the word "chart" with the words "develop", "quality" and "sample" shows that the studies used samples for the development of control charts for quality monitoring.

\section{CONCLUSION}

This paper aimed at the accomplishment of a Systematic Literature Review (SLR) through mapping the theme "multivariate control charts" in Brazilian research published in the periodical of the Web of Science. A research protocol was systematized according to the methodological rigidity imposed to this type of analysis, being the innovation of this research the use of three robust techniques applied to SLR in the investigation of the proposed theme. The detailed presentation phase of the research corpus pointed out that the institutions with the highest number of publications on the subject are the State University of Campinas (UNICAMP), followed by Goiano Federal Institute (IFGoiano) and Federal University of Uberlândia (UFU), and the State of Minas Gerais is more representative in terms of publications.

It is possible to notice a growing tendency of the publications over the years, which shows the high potential of the research on the subject in Brazil. The work with the largest number of citations was Borin and Poppi's (2004) and the periodicals most used as means of dissemination of the publications were: Microchemical Journal and Journal of the Brazilian Chemical Society.

It was also noticed the existence of an internationalization of the researches on the issue, since, the textual corpus counted on the collaboration of eight foreign institutions. The 
analysis of the co-citation network evidenced relevant authors for research in this area, such as Harold Hotelling, Douglas Montgomery, and John Frederick MacGregor. Another important finding was the presence of important Brazilian researchers on the subject, such as Werickson Rocha, Jefferson de Oliveira, Fernanda Saadna Lopes da Costa, Júlio Alves, and Maria Fernanda Pimentel, who are generally researchers with a background in Chemistry, Chemometrics and Qualimetry, in the health and biodiesel area.

It was possible to notice that the publications of the corpus of the research have as objective the use of the multivariate control charts for the quality monitoring, having a greater application focus in the pharmaceutical and biodiesel industries. The methodologies used have a more quantitative approach, presenting satisfactory results for the control of process quality. Therefore, from this study it was evident the relevance of deepening the research on this issue, that is, multivariate control charts, since the Brazilian academic community is gradually being inserted in the international context through collaborations between foreign institutions, publications of papers in other languages and use of high-quality media.

\section{References}

ABREU, R. P.; SCHAFFER, J. R. A Double EWMA Control Chart for the Individuals Based on a Linear Prediction. Journal of Modern Applied Statistical Methods, v. 16, n. 2, p.443457, 2017.

ALABI, G. Bradford's law and its application. International Library Review, v. 11, n. 1, p.151-158, 1979.

ALMEIDA, C. P. B.; GOULART, B. N. G. How to avoid bias in systematic reviews of observational studies. Revista CEFAC, v. 19, n. 4, p.551-555, 2017.

ANDOR, M. A.; FELS, K. M. Behavioral economics and energy conservation-a systematic review of non-price interventions and their causal effects. Ecological economics, v. 148, p.178-210, 2018.

ARCHER, J. M. J.; HOSTETLER, M. E.; ACOMB, G.; BLAIR, R. A systematic review of forest bird occurrence in North American forest fragments and the built environment. Landscape and Urban Planning, v. 185, p.1-23, 2019.

ASSIS, T. F.; LOPES, D. M. M.; PEDRO, L. M.; DA SILVA, M. A. V. Revisão sistemática de estudos de viabilidade em transporte: uma contribuição para o transporte hidroviário. GEPROS. Revista Gestão da Produção Operações e Sistemas, v. 12, n. 4, p.1, 2017. In Portuguese. 
AVILA, T. C.; POPPI, R. J.; LUNARDI, I.; TIZEI, P. A.; PEREIRA, G. A. Raman spectroscopy and chemometrics for on-line control of glucose fermentation by Saccharomyces cerevisiae. Biotechnology progress, v. 28, n. 6, p.1598-1604, 2012.

BALESTRASSI, P. P., PAIVA, A. P., SOUZA, A. C. Z., TURRIONI, J. B., POPOVA, E. A multivariate descriptor method for change-point detection in nonlinear time series. Journal of Applied Statistics, v. 38, n. 2, p.327-342, 2011.

BARROSO, J.; GOLLOP, C. J.; SANDELOWSKI, M.; MEYNELL, J.; PEARCE, P.F.; COLLINS, L.J. The Challenges of Searching for and Retrieving Qualitative Studies. Western Journal of Nursing Research, v. 25, n. 2, p.153-78, 2003.

BASTIAN, M.; HEYMANN, S.; JACOMY, M. Gephi: An Open Source Software for Exploring and Manipulating Networks. Icwsm, v. 8, p. 361-362, 2009.

BIOLCHINI, J. C. D. A.; MIAN, P. G.; NATALI, A. C. C.; CONTE, T. U.; TRAVASSOS, G. H. Scientific research ontology to support systematic review in software engineering. Advanced Engineering Informatics, v. 21, n. 2, p.133-151, 2007.

BORIN, A.; POPPI, R. J. Multivariate quality control of lubricating oils using Fourier transform infrared Spectroscopy. Journal of the Brazilian Chemical Society, v. 15, n. 4, 570-576, 2004.

BRADFORD, S. C. Documentation. London, Crosby Lockwood; Washington, Public Affairs Press, 1953.

CHAN, Z. C.; YAN, C. H.; JASON, C. H. C.; NGA, C. S.; YAN, N. K.; YIU, W. K.; KAN, Y. P. Academic advising in undergraduate education: A systematic review. Nurse Education Today, v. 75, p. 58-74, 2019.

COSTA, F. S. L.; PEDROZA, R. H. P.; PORTO, D. L.; AMORIM, M. V. P.; LIMA, K. M. G. Multivariate Control Charts for Simultaneous Quality Monitoring of Isoniazid and Rifampicin in a Pharmaceutical Formulation Using a Portable Near Infrared Spectrometer. Journal of the Brazilian Chemical Society, v. 26, n. 1, p.64-73, 2015.

DARMANTO, S.; ASTUTIK, S. The effectiveness of robust RMCD control chart as outliers detector. Journal of Physics, v. 943, n. 1, 2017.

DELIBERADOR, L. R.; DE MELLO, L. T. C.; BATALHA, M. O. Perdas de Grãos no Transporte e Armazenagem: Uma Revisão Sistemática da Literatura com Análise Bibliométrica. GEPROS. Revista Gestão da Produção Operações e Sistemas, v. 14, n. 5, p.174, 2019. In Portuguese.

DRESCH, A.; LACERDA, D. P.; JÚNIOR, J. A. V. A. Design science research: research method for the advancement of science and technology. New York: Springer, 2015.

FAISAL, M.; ZAFAR, R. F.; ABBAS, N.; RIAZ, M.; MAHMOOD, T. A modified CUSUM control chart for monitoring industrial processes. Quality and Reliability Engineering International, v. 34, n. 6, p.1045-1058, 2018. 
FRUCHTERMAN, T. M. J.; REINGOLD, E. M. Graph drawing by force-directed placement. Software: Practice and experience, v. 21, n. 11, p.1129-1164, 1991.

GALAVERNA, R.; RIBESSI, R.L.; ROHWEDDER, J. J. R.; PASTRE, J. C. Coupling Continuous Flow Microreactors to MicroNIR Spectroscopy: Ultracompact Device for Facile In-Line Reaction Monitoring. Organic Process Research \& Development, v. 22, n. 7, p.780-788, 2018.

GREENHALGH, T. Papers that summarise other papers (systematic reviews and metaanalyses). BMJ, v. 13, n. 315, 1997.

GRAEFF, N.; JONGSMA, K. R.; JOHNSTON, J.; HARTLEY, S.; BREDENOORD, A. L. The ethics of genome editing in non-human animals: a systematic review of reasons reported in the academic literature. Philosophical Transactions of the Royal Society B, v. 374, n. 1772, p.20180106, 2019.

GUTIERREZ-SALAZAR, P.; MEDRANO-VIZCAINO, P. The effects of climate change on decomposition processes in andean paramo ecosystem-synthesis, a systematic review. Applied Ecology and Environmental Research, v. 17, n. 2, p.4957-4970, 2019.

HAQ, A.; GULZAR, R.; KHOO, M. B. C. An efficient adaptive EWMA control chart for monitoring the process mean. Quality and Reliability Engineering International, v. 34, n. 4, p.563-571, 2018.

HAIR, J. F.; BLACK, W. C.; BABIN, B. J.; ANDERSON, R. E.; TATHAM, R. L. Análise Multivariada de Dados. Porto Alegre: Bookman Editora, 2009. In Portuguese.

HENNING, E.; MAIA, M. T.; WALTER, O. M. F. C.; KONRATH, A. C.; CUNHA, C. A. Application of hotelling's $\mathrm{T}^{2}$ control chart for a machining process of the inside diameter of a steel cylinder. GEPROS. Revista Gestão da Produção Operações e Sistemas, v. 9, n. 2, p.155, 2014.

HUANG, Y.; SCHUEHLE, J.; PORTER, A. L.; YOUTIE, J. A systematic method to create search strategies for emerging technologies based on the Web of Science: illustrated for 'Big Data'. Scientometrics, v. 105, n. 3, p.2005-2022, 2015.

KIM, S.; JEONG, M. K.; ELSAYED, E. A. Generalized smoothing parameters of a multivariate EWMA control chart. Quality \& Reliability Engineering, v. 49, n. 1, p.58-69, 2017.

KITCHENHAM, B. Procedures for Performing Systematic Reviews. Keele, UK, Keele University, v. 33, p. 1-26, 2004.

LOTKA, A. J. The frequency distribution of scientific productivity. Journal of the Washington Academy of Sciences, v. 16, n. 12, p.317-323, 1926.

LYU, J., CHEN, M. Automated visual inspection expert system for multivariate statistical process control chart. Expert Systems with Applications, v. 36, n. 3, p.5113-5118, 2009. 
MABOUDOU-TCHAO, E. M.; SILVA, I. R.; DIAWARA, N. Monitoring the mean vector with Mahalanobis kernels. Quality Technology \& Quantitative Management, v. 15, n. 4, p.459-474, 2018.

MACHADO, M. A. G.; COSTA, A. F. B.; MARINS, F. A. S. Control charts for monitoring the mean vector and the covariance matrix of bivariate processes. The International Journal of Advanced Manufacturing Technology, v. 45, n. 7-8, p.772-785, 2009.

MARCONDES FILHO, D.; FOGLIATTO, F. S.; OLIVEIRA, L. P. L. Gráficos de controle multivariados para monitoramento de processos não lineares em bateladas. Production, v. 21, n. 1, p.132-148, 2011. In Portuguese.

MASON, R. L.; YOUNG, J. C. Multivariate Statistical Process Control with Industrial Applications. Siam: Philadelphia, 2002.

MCDONALD, S.; CRUMLEY, E.; EISINGA, A.; VILLANUEVA, E. Search strategies to identify reports of randomized trials in MEDLINE: protocol for a Cochrane review. Oxford: The Cochrane Library, 2006.

MICHELS, C.; FU, J. Y. Systematic analysis of coverage and usage of conference proceedings in web of science. Scientometrics, v. 100, n. 2, p.307-327, 2014.

MONDOLO, J. How do informal institutions influence inward FDI? A systematic review. Economia Politica, v. 36, n. 1, p.167-204, 2019.

MONTERO, A. C. G.; AGUADED, I.; FERRES, J. Competencia mediática organizacional: Una revisión sistemática de literatura científica en Web of Science. DIXIT, v. 27, p.74, 2017. In Spanish.

MONTGOMERY, D. C. Introdução ao Controle Estatístico da Qualidade. 7.ed. Rio de Janeiro: LTC, 2016. In Portuguese.

MORAES, D. A. O.; OLIVEIRA, F. L. P.; QUININO, R. C.; DUCZMAL, L. H. Self-oriented control charts for efficient monitoring of mean vectors. Computers \& Industrial Engineering, v. 75, p.102-115, 2014.

MORALES, S. O. C. Economic Statistical Design of Integrated X-bar-S Control Chart with Preventive Maintenance and General Failure Distribution. PloS one, v. 8, n. 3, p.e59039, 2013.

NEWMAN, M. E. J. Modularity and community structure in networks. Proceedings of the national academy of sciences, v. 103, n. 23, p.8577-8582, 2006.

NEWTON, G.; RACEY, M.; MARQUEZ, O.; MCKENNEY, A.; PREYDE, M.; WOSNICK, D. A Systematic Review of Tools Measuring Nutrition Knowledge of Pre-Adolescents and Adolescents in a School-Based Setting. Journal of School Health, v. 89, n. 5, p.402-417, 2019.

NIDSUNKID, S.; BORKOWSKI, J. J.; BUDSABA, K. The Performance of MCUSUM 
Control Charts when the Multivariate Normality Assumption is Violated. Thailand Statistician, v. 16, n. 2, p.140-155, 2018.

OLIVEIRA, I. K.; ROCHA, W. F.; POPPI, R. J. Application of near infrared Spectroscopy and multivariate control charts for monitoring biodiesel blends. Analytica Chimica Acta, v. 642, n. 1-2, p.217-221, 2009.

PAN, J. N.; LEE, C. Y. New Capability Indices for Evaluating the performance of Multivariate Manufacturing Process. Quality and Reliability Engineering International, v. 26, n. 1, p.3-15, 2010.

PEDRINI, M.; LANGELLA, V.; BATTAGLIA, M. A.; ZARATIN, P. Assessing the health research's social impact: a systematic review. Scientometrics, v.114, n. 3, p.1227-1250, 2018.

PRADO, A. E.; CAMPO, F. C. Bibliometric analysis 1990-2014: Competitive Intelligence. Perspectiva em Ciência da Informação, v.23, n.1, p.71-88, 2018.

PRELL, C. Social network analysis: History, theory and methodology. SAGE Publications Ltd: New York, 2011.

QIU, P. Some perspectives on nonparametric statistical process control. Journal of Quality Technology, v. 50, n. 1, p.49-65, 2018.

RAFOLS, I.; PORTER, A.; LEYDESDORFF, L. Science overlay maps: A new tool for research policy and library management. Journal of the Association for Information Science and Technology, v. 61, n. 9, p.1871-1887, 2010.

RATINAUD, P.; DÉJEAN, S. IRaMuTeQ: implementation de la méthode ALCESTE d'analyse de texte dans un logiciel libre. Modélisation appliquée aux sciences humaines et sociales, p.8-9, 2009. in French.

REIS, F.; GUIMARÃES, F.; NOGUEIRA, L. C.; MEZIAT-FILHO, N.; SANCHEZ, T. A.; WIDEMAN, T. Association between pain drawing and psychological factors in musculoskeletal chronic pain: A systematic review. Physiotherapy theory and practice, v. 35, n. 6, p.533-542, 2019.

ROCHA, W. F. C.; POPPI, R. J. Multivariate control charts based on net analyte signal (NAS) for characterization of the polymorphic composition of Piroxicam using near infrared spectroscopy. Microchemical Journal, v. 96, n. 1, p.21-26, 2010.

ROCHA, W. F.; ROSA, A. L.; MARTINS, J. A.; POPPI, R. J. Multivariate control charts based on net analyte signal and near infrared spectroscopy for quality monitoring of Nimesulide in pharmaceutical formulations. Journal of Molecular Structure, v. 982, n. 1-3, p.73-78, 2010.

ROCHA, W. F.; POPPI, R. J. Multivariate control charts based on net analyte signal (NAS) and Raman spectroscopy for quality control of carbamazepine. Analytica Chimica Acta, v. 705, n. 1-2, p.35-40, 2011. 
RUIZ-NEGRÓN, N.; MENON, J.; KING, J. B.; MA，J.; BELlOWS, B. K. CostEffectiveness of Treatment Options for Neuropathic Pain: a Systematic Review. Pharmaco Economics, v. 37, n. 5, p.669-688, 2019.

SITOE, B. V.; MITSUTAKE, H.; GUIMARAES, E.; GONTIJO, L. C.; SANTOS, D. Q.; NETO, W. B. Quality Control of Biodiesel Content of B7 Blends of Methyl Jatropha and Methyl Crambe Biodiesels Using Mid-Infrared Spectroscopy and Multivariate Control Charts Based on Net Analyte Signal. Energy \& Fuels, v. 30, n. 2, p.1062-1070, 2016.

SITOE, B. V.; MÁQUINA, A. D. V.; SANTANA, F. B.; GONTIJO, L. C.; SANTOS, D. Q.; NETO, W. B. Monitoring of biodiesel content and adulterant presence in methyl and ethyl biodiesels of jatropha in blends with mineral diesel using MIR spectrometry and multivariate control charts. Fuel, v. 191, p.290-299, 2017.

SCHMITZ, E.; FIGUEIRA, S.; LAMPRON, J. Injury prevention in medical education: a systematic literature review. Journal of Surgical Education, v. 76, n. 3, p.700-710, 2019

SORIANO, A.; ÁLVAREZ, C. L.; VALDÉS, R. M. T. Bibliometric analysis to identify an emerging research area: Public Relations Intelligence - a challenge to strengthen technological observatories in the network society. Scientometrics, v. 115, n. 3, p.1591-1614, 2018.

SUKPARUNGSEE, S.; KUVATTANA, S.; BUSABABODHIN, P.; AREEPONG Y. Multivariate copulas on the MCUSUM control. Cogent Mathematics, v. 4, n. 1, p.1342318, 2017.

TEIXEIRA, R. C.; SOUZA, C. Evolução da inteligência competitiva com base em estudo métrico de sua literatura. Perspectivas em Ciência da Informação, v. 22, n. 1, p. 170-185, 2017. In Portuguese.

TÔRRES, A. R.; GRANGEIRO JUNIOR, S.; FRAGOSO, W. D. Multivariate control charts for monitoring captopril stability. Microchemical Journal, v. 118, p.259-265, 2015.

TRANFIELD, D.; DENYER, D.; SMART, P. Towards a Methodology for Developing Evidence-Informed Management Knowledge by Means of Systematic Review. British Journal of Management, v. 14, p.207-222, 2003.

UGAZ, W.; SÁNCHEZ, I.; ALONSO, A. M. Adaptive EWMA control charts with timevarying smoothing parameter. The International Journal of Advanced Manufacturing Technology, v. 93, n. 9-12, p.3847-3858, 2017.

VIZEU. C. B.; JUSTO, A. M. IRAMUTEQ: um software gratuito para análise de dados textuais. Temas em psicologia, v. 21, n. 2, 2013.

WANG, R.F.; FU, X.; YUAN, J.; DONG, Z. Economic design of variable-parameter (X)overbar-Shewhart control chart used to monitor continuous production. Quality Technology \& Quantitative Management, v. 15, n. 1, p.106-124, 2018.

XIANG, Y. Joint optimization of X control chart and preventive maintenance policies: A discrete-time Markov chain approach. European Journal of Operational Research, v. 229, 
n. 2, p.382-390, 2013.

YIN, H.; ZHANG, G.; ZHU, H.; DENG, Y.; HE, F. An integrated model of statistical process control and maintenance based on the delayed monitoring. Reliability Engineering and System Safety, v. 133, p.323-333, 2015.

ZIPF, G. K. Human behavior and the principle of least effort. Cambridge, MA: Addison Wesley, 1949.

ZUPIC, I.; ČATER, T. Bibliometric methods in management and organization. Organizational Research Methods, v. 18, n. 3, p.429-472, 2015. 